\title{
Artikel Review: Produksi Gas Hidrogen dari Reaksi Elektrolisis Sebagai Bahan Bakar Non-Fosil
}

\author{
Ismi Nurlatifah ${ }^{1)}$ dan Lily Arlianti ${ }^{2)}$ \\ Program Studi Teknik Kimia, Fakultas Teknik, Universitas Islam Syekh Yusuf, Jl. Mulana Yusuf No.10 Tangerang \\ Banten 15118, Indonesia \\ 1) isminurlatifah@unis.ac.id \\ ${ }^{2)}$ larlianti@unis.ac.id

\begin{abstract}
Abstrak. Dalam menjalani berbagai aktivitas di zaman sekarang, banyak hal yang tidak bisa terlepas dari yang namanya bahan bakar. Seperti yang kita ketahui bersama, bahan bakar yang masih umum digunakan hingga saat ini adalah bahan bakar fosil yang sumber daya energinya semakin menipis. Tidak hanya itu, bahan bakar fosil pun terbukti dapat menghasilkan polusi udara. Kondisi udara yang tidak sehat tentunya dapat menurunkan harapan hidup manusia. Agar lingkungan menjadi bersih dan tidak secara terus menerus tercemar dengan adanya polusi udara, harus ada bahan bakar yang ramah lingkungan. Bahan bakar tersebut adalah hidrogen yang berasal dari nonfosil. Salah satu cara untuk memperoleh hidrogen adalah reaksi elektrolisis dengan bahan baku air. Hanya dengan beberapa liter air saja, proses ini dapat menghasilkan sepuluh hingga dua puluh ribu liter gas Hidrogen per jam. Cara lain untuk memperoleh gas hidrogen adalah melalui steam methane reforming (SMR), petroleum refining dan coal gasification. Penggunaan Hidrogen sebagai bahan bakar nonfosil telah terbukti sebagai bahan bakar yang ramah lingkungan dan free of carbon monoxide. Udara yang sehat dan lingkungan yang bersih tentunya merupakan tanggung jawab kita bersama. Saatnya untuk beralih ke penggunaan bahan bakar hidrogen.
\end{abstract}

Kata kunci: hidrogen, elektrolisis, bahan bakar

\begin{abstract}
The Production of Hydrogen Gas from Electrolysis as Non-Fossil Fuels]. In carrying out various activities today, it cannot be separated from the fuel. As we all know, fuels that are still commonly used today are fossil fuels whose energy resources are running low. Not only that, fossil fuels have also been shown to produce air pollution. Unhealthy air conditions can certainly reduce human life expectancy. In order to make the clean environment and not polluted by the air pollution, there must be environmentally friendly fuels. The answer for this kind of fuels is hydrogen which comes from nonfossil. One way to obtain hydrogen is an electrolysis with water as raw material. Just a few liters of water, it can produce ten to twenty thousand liters of hydrogen gas per hour. Other ways to obtain hydrogen gas are steam methane reforming (SMR), petroleum refining, and coal gasification. The use of Hydrogen as a non-fossil fuel has been proven to be environmentally friendly and free of carbon monoxide. Healthy air and a clean environment are certainly our responsibility. It's time to switch by using hydrogen fuel.
\end{abstract}

Keywords: hydrogen, electrolysis, fuel

\section{Pendahuluan}

Penggunaan bahan bakar dalam menjalani aktivitas sehari-hari menjadi suatu hal yang umum bahkan sering dijumpai. Aktivitas manusia dimulai dari mengolah makanan, bergerak dari satu tempat ke tempat yang lain menggunakan transportasi, sampai pada penerangan cahaya selalu membutuhkan bahan bakar. Semakin sangat digunakannya bahan bakar semakin banyak pula bahan bakar yang diperlukan. Dengan meningkatnya permintaan bahan bakar dari hari ke hari membuat semakin menipisnya persediaan sumber daya energi fosil.
Tidak hanya karena ketersediaannya yang menipis, bahan bakar dari energi fosilpun dapat menghasilkan polusi udara. Semakin meningkatnya konsentrasi polutan di udara tentunya membuat kondisi lingkungan menjadi tidak sehat. Penggunaan energi fosil juga dapat menimbulkan efek rumah kaca (Marline, E., 2013). Menurut Michael Greenstone dan Qing Claire Fan (2019), terjadi peralihan status kondisi udara di Indonesia. Indonesia yang awalnya merupakan salah satu negara paling bersih menjadi salah satu dari $20 \%$ negara paling berpolusi. Terjadi peningkatan konsentrasi polutan hingga mencapai $171 \%$. 
Tidak dapat dipungkiri bahwa salah satu penyumbang terjadinya polusi udara adalah transportasi. Di satu sisi dengan adanya transportasi memudahkan dalam beraktivitas tapi di sisi lain dengan transportasi yang digunakan menimbulkan polusi.

Dilihat dari dua aspek yaitu ketersediaan yang menipis dan efek buruk yang ditimbulkan membuat banyak pihak yang mulai beralih untuk membuat bahan bakar dari sumber energi non fosil. Bahan bakar tersebut adalah gas hidrogen. Hidrogen merupakan unsur yang jumlahnya melimpah di alam, namun masih berikatan dengan unsur-unsur yang lain membentuk molekul seperti air dan minyak bumi. Jadi Hidrogen itu sendiri perlu diproduksi dengan cara memecah unsur Hidrogen dari molekulnya. Oleh karena itu Hidorgen bukan termasuk sumber energi (energy source) melainkan pembawa energi (carrier energy). Hidrogen akan menjadi sistem energi masa depan di seluruh dunia (Gallardo, 2020). Beberapa poin penting jika digunakan bahan bakar hidrogen, yaitu : 1) rentang pembakaran yang luas, 2) energi pengapian yang rendah, 3) jarak pendinginan yang kecil, 4) Kecepatan yang tinggi untuk pembakaran, dan 5) memiliki difusivitas yang tinggi (Bhardwaj, 2014).

Sarana transportasi berbahan bahar Hidrogen sudah diproduksi. Menurut Raju Febian (2018) dalam tulisannya yang berjudul "Honda Clarity Fuel Cell, The Silent Future", Honda telah menghadirkan sebuah mobil berbahan bakar Hidrogen. Bahan bakar tersebut ada di dalam tangki yang tentunya aman karena terbuat dari carbon fiber dengan kapasitas 141 liter. Dengan kapasitas tersebut, kendaraannya mampu menempuh jarak hingga sejauh $750 \mathrm{~km}$. Tidak hanya ramah lingkungan karena near zero emission tetapi juga menghadirkan kenyamanan berkendara yang maksimal.

Untuk memperoleh gas Hidrogen, salah satu cara yang dapat dilakukan adalah dengan elektrolisis air.berbagai cara, diantaranya: Steam Methane Reforming (SMR), Petroleum Refining, Coal Gasification, dan Elektrolisis.

Melalui reaksi elektrolisis, gas Hidrogen dapat diperoleh dari sumber daya domestik yang berlimpah yaitu air. Salah satu negara yang sudah mengembangkan teknologi ini adalah negara Australia. Mesin yang mereka miliki mampu menghasilkan sepuluh hingga dua puluh ribu liter gas Hidrogen per jam hanya dengan beberapa liter air saja.

Bahan bakar Hidrogen merupakan bahan bakar yang sangat menarik. Tidak hanya bisa diperoleh dari sumber daya yang melimpah tetapi juga ramah lingkungan, free of carbon monoxide (CO), dan bersih (McMurry, 2003). Bahan bakar itu sendiri bisa masuk ke berbagai aspek termasuk rumah tangga, transportasi, dan juga sumber energi.

\section{Metode dan Pembahasan}

Untuk memperoleh gas Hidrogen dapat dilakukan beberapa cara, diantaranya:

\section{Steam Methane Reforming (SMR)}

Sebanyak $48 \%$ di dunia memproduksi dengan cara ini. Dari $48 \%$ tersebut, hampir sebanyak $95 \%$ Hidrogen diproduksi oleh Negara Amerika. Mereka menganggap bahwa Hidrogen merupakan barang yang komersil.

Berdasarkan data energi tahun 2010, di Negara Amerika sudah memiliki sebanyak 313 kendaraan berbahan bakar Hidrogen dan sebanyak 70 tempat pengisian bahan bakar hidrogen.

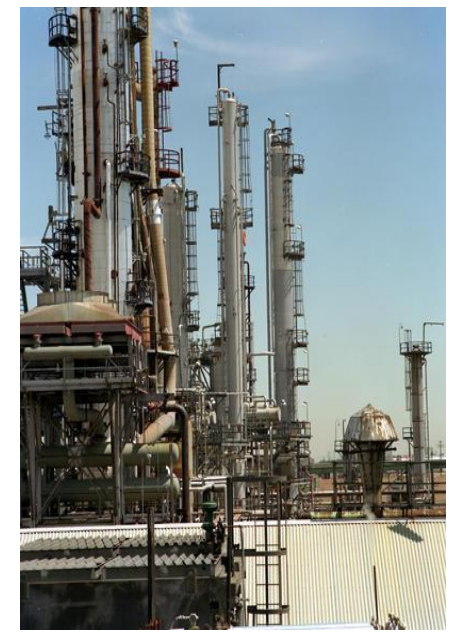

Gambar 1. Produksi gas Hidrogen dengan Teknik SMR

Teknik SMR terdiri atas tiga tahap. Tahap pertama yaitu konversi uap dan metana $\left(\mathrm{CH}_{4}\right)$ menjadi gas karbon monoksida dan hidrogen.

$$
\begin{aligned}
& \mathrm{H}_{2} \mathrm{O}(g)+\mathrm{CH}_{4}(g) \stackrel{1100^{\circ} \mathrm{C}}{\longrightarrow}+3 \mathrm{H}_{2}(g) \\
& \otimes \mathrm{H}^{0}=+206 \mathrm{~kJ} \quad(1)
\end{aligned}
$$

Agar reaksi dapat berlangsung diperlukan kondisi tekanan yang cukup tinggi, suhu tinggi dan penambahan katalis Nikel (Ni). Tahap kedua, dilakukan reaksi pergeseran air-gas dengan bantuan katalis oksida logam dan berlangsung pada suhu $400^{\circ} \mathrm{C}$.

$$
400^{\circ} \mathrm{C}
$$$$
\mathrm{CO}(g)+\mathrm{H}_{2} \mathrm{O}(g) \square \mathrm{CO}_{2}(g)+\mathrm{H}_{2}(g) \otimes \mathrm{H}^{0}=-41 \mathrm{~kJ}
$$

Pada tahap kedua ini, gas karbon monoksida (CO) yang beracun diubah menjadi gas karbondioksida $\left(\mathrm{CO}_{2}\right)$ dan diperoleh lebih banyak gas $\mathrm{H}_{2}$. Tahap terakhir yaitu menghilangkan gas $\mathrm{CO}_{2}$ dengan melewatkan campuran dalam larutan basa. Dengan perlakuan tersebut, $\mathrm{CO}_{2}$ berubah menjadi ion karbonat $\left(\mathrm{CO}_{3}{ }^{2-}\right)$ berfasa larutan.

$$
\mathrm{CO}_{2}(g)+2 \mathrm{OH}^{-}(a q) \square \mathrm{CO}_{3}{ }^{2-}(a q)+\mathrm{H}_{2} \mathrm{O}(l)(3)
$$

Gas Hidrogen yang dihasilkan melalui reaksi ini memang lebih banyak dibandingkan dengan teknik yang lain namun masih tetap digunakan sumber daya energi tidak terbarukan yaitu $\mathrm{CH}_{4}$ (Takenaka dalam Ariawan, 2010). 
Jurnal Pendidikan dan Aplikasi Industri (UNISTEK)

Vol. 8 No. 1 Februari 2021

p- ISSN : 0126 - 4036

e- ISSN : $2716-0416$

\section{Petroleum Refining dan Coal Gasification}

Sebanyak 30\% di dunia menggunakan teknik ini dalam memproduksi Hidrogen. Untuk teknik coal gasification, sebanyak $18 \%$ di dunia menggunakan teknik tersebut terutama untuk negara-negara di Eropa dan Asia.

\section{Elektrolisis}

Produksi Hidrogen melalui teknik elektrolisis di dunia baru mencapai $4 \%$. Hidrogen yang dihasilkan memiliki tingkat kemurnian yang tinggi yaitu mencapai lebih dari 99,95\%. Untuk berlangsungnya reaksi elektrolisis ini dibutuhkan energi yang besar yaitu $-286 \mathrm{~kJ} / \mathrm{mol}$ gas $\mathrm{H}_{2}$. Persamaan reaksinya adalah sebagai berikut:

$$
2 \mathrm{H}_{2} \mathrm{O}(l) \square 2 \mathrm{H}_{2}(g)+\mathrm{O}_{2}(g) \otimes \mathrm{H}^{0}=+572 \mathrm{~kJ}(4)
$$$$
\text { Elektrolisis melibatkan arus }
$$

listrik yang menghasilkan reaksi kimia (McMurry, 2003). Reaksi-reaksi kimia pada proses elektrolisis diantaranya adalah reaksi reduksi dan reaksi oksidasi. Pada reaksi oksidasi terjadi kenaikan bilangan oksidasi dan juga pelepasan elektron (Whitten, 2014), sedangkan reaksi reduksi adalah kebalikannya. Pada reaksi reduksi terjadi penurunan bilangan oksidasi dan penerimaan elektron. Bilangan oksidasi suatu unsur adalah muatan suatu atom dalam senyawa (Syukri, 1999). Reaksi oksidasi berlangsung di anode (kutub positif $(+))$ dan reaksi reduksi berlangsung di katode (kutub negatif (-)). Katode dan anode merupakan elektroda. Elektroda ini berfungsi untuk menghantarkan arus listrik dari sumber tegangan ke air yang akan dielektrolisis. Reaksi yang dimaksud dituliskans sebagai berikut :

Anoda (+) : $2 \mathrm{OH}^{-} \mathrm{Q} 1 / 2 \mathrm{O}_{2}+\mathrm{H}_{2} \mathrm{O}+2 \mathrm{e}^{-}$

Katoda (-) : $2 \mathrm{H}_{2} \mathrm{O}+2 \mathrm{e}^{-} \square \mathrm{H}_{2}+2 \mathrm{OH}^{-}$

Total reaksi : $\mathrm{H}_{2} \mathrm{O} \square 1 / 2 \mathrm{O}_{2}+\mathrm{H}_{2}$

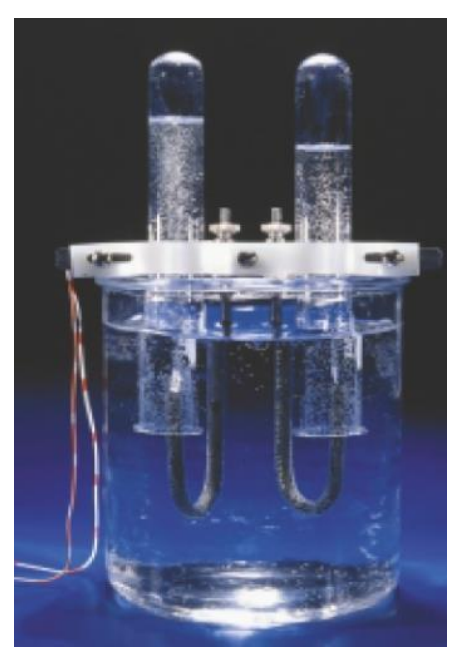

Gambar 2. Reaksi Elektrolisis Air yang menghasilkan Gas Hidrogen pada Elektroda Satu dan Gas Oksigen pada Elektroda lainnya

Sumber : McMurry

Selain elektroda, komponen lainnya yang harus ada pada saat proses elektrolisis berlangsung adalah larutan elektrolit. Larutan elektrolit adalah larutan yang di dalamnya mengandung ion-ion (Sunarya, 2007). Pemilihan dan komposisi larutan elektrolit yang digunakan berpengaruh terhadap gas $\mathrm{H}_{2}$ yang dihasilkan.

Penelitian yang dilakukan oleh Marlina (2013) bertujuan untuk mengetahui hubungan antara persentase $\mathrm{NaHCO}_{3}$ (Natrium Bikarbonat) dan jumlah energi elektrolisis terhadap laju pembentukan gas $\mathrm{H}_{2}$ pada proses elektrolisis, serta mendapatkan persentase $\mathrm{NaHCO}_{3}$ (Natrium Bikarbonat) yang terbaik pada produksi gas HHO (Brown's Gas). Brown's Gas merupakan gas hasil elektrolisis yang terdiri dari 2 Hidrogen dan 1 Oksigen (HHO) yang dapat diilustrasikan melalui Gambar 3. Larutan $\mathrm{NaHCO}_{3}$ merupakan larutan elektrolit dan bertindak sebagai katalis dalam reaksi elektrolisis.

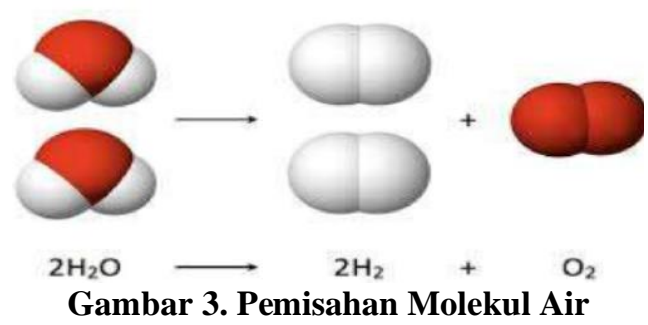

(Sumber : Mamilla, 2018)

Skema percobaan pada penelitian ini dapat dilihat pada Gambar 4. 


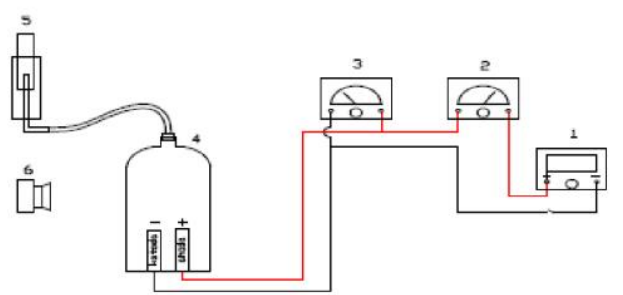

1. Battery charger

2. Volt meter

4. Elektrolizer
5. Gelas ukur +
stop watch
6. Kamera

3. Amperemeter

Gambar 4. Instalasi penelitian produksi Gas HHO (Brown's Gas).

Parameter yang digunakan pada penelitian ini: 1) Daya yang dibutuhkan untuk proses produksi HHO, 2) Laju produksi /flow rate gas $\mathrm{HHO}$, dan 3) Efisiensi Generator HHO. Untuk parameter yang pertama diperoleh persentase $\mathrm{NaHCO}_{3}$ optimum sebesar $12,5 \%$ dengan daya yang dihasilkan sebesar 280 watt terlihat pada Gambar 5.

Terlihat pada grafik di Gambar 5, pada awalnya seiring dengan bertambahnya persentase $\mathrm{NaHCO}_{3}$ bertambah pula nilai konsumsi dayanya. Hal tersebut menandakan semakin banyak $\mathrm{NaHCO}_{3}$ yang digunakan maka semakin banyak pula ion yang dihasilkan didalam larutan yang menyebabkan semakin besar arus listrik yang dihasilkan. Arus listrik sendiri menjadi acuan untuk berlangsungnya reaksi elektrolisis. Namun semakin lama kondisinya tidak demikian, larutan $\mathrm{NaHCO}_{3}$ akan mencapai kondisi jenuhnya yang menyebabkan pergerakan ion-ionnya menjadi terbatas.

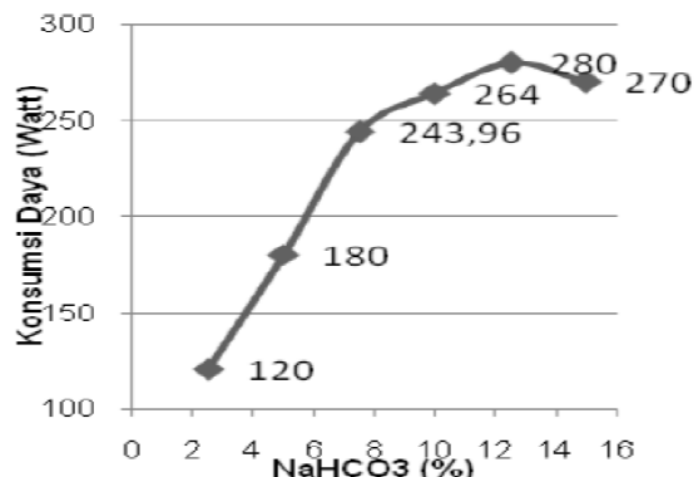

Gambar 5. Hubungan presentase $\mathrm{NaHCO}_{3}$ terhadap konsumsi daya

Untuk parameter yang kedua, hasilnya dapat dilihat pada Gambar 6.

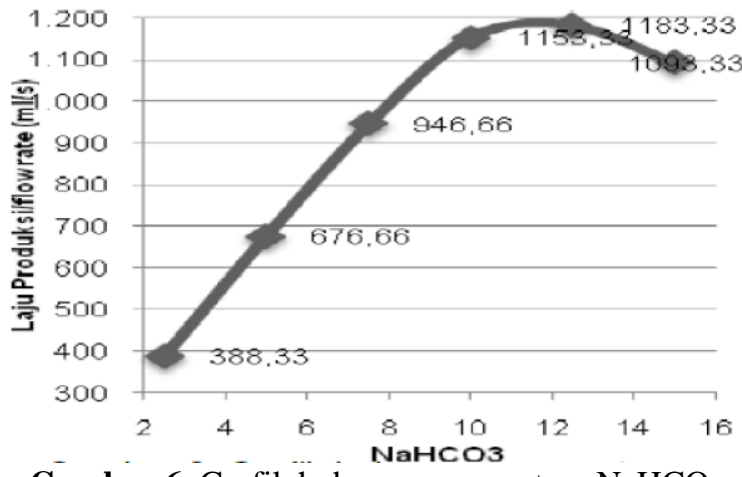

Gambar 6. Grafik hubungan presentase $\mathrm{NaHCO}_{3}$ terhadap laju produksi (flow rate) $\mathrm{HHO}$

Laju produksi $\mathrm{HHO}$ semakin meningkat seiring dengan bertambahnya $\mathrm{NaHCO}_{3}$. Hal tersebut dikarenakan semakin banyak arus listrik untuk reaksi elektrolisis yang mengakibatkan semakin banyaknya gas $\mathrm{HHO}$ yang dihasilkan. Namun tetap akan sampai pada kondisi jenuhnya untuk $\mathrm{NaHCO}_{3}$ yang menyebabkan pergerakan ion-ionnya terbatas. Persentase optimum untuk $\mathrm{NaHCO}_{3}$ diperoleh sebesar 12,5\%.

Nilai presentase optimum $\mathrm{NaHCO}_{3}$ untuk parameter efisiensi generator $\mathrm{HHO}$ adalah sebesar $18,95 \%$ dapat dilihat pada Gambar 7 .

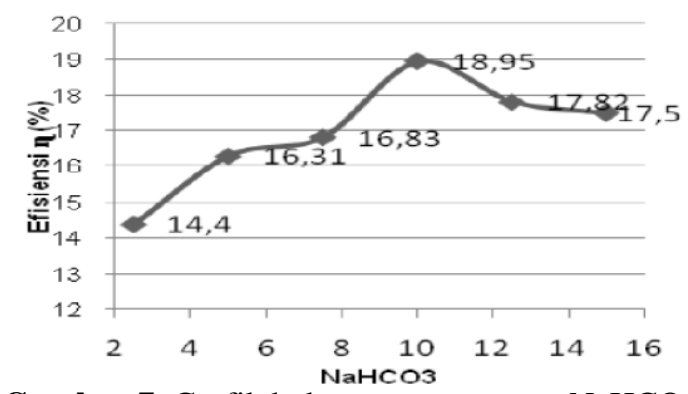

Gambar 7. Grafik hubungan presentase $\mathrm{NaHCO}_{3}$ terhadap efisiensi generator $\mathrm{HHO}$

Awalnya trend grafik terlihat menanjak kemudian menurun setelah persentase $18,95 \%$. Hal tersebut dikarenakan dengan semakin besarnya energi listrik yang mengalir membuat semakin banyak energi listrik yang berubah menjadi panas yang kemudian terlepas ke lingkungan sehingga membuat kinerja generator semakin berkurang.

Penelitian lebih lanjut dilakukan oleh Suprianto (2016). Tujuan dilakukannya penelitian adalah untuk mengetahui pengaruh larutan $\mathrm{NaHCO}_{3}$ pada proses elektrolisis terhadap penghematan bahan bakar. Reaksi elektrolisis berlangsung di alat elekrolizer dengan skema yang dapat dilihat pada Gambar 8 dan 9 .
Selang bensin yang menghubungkan botol dengan karburator 


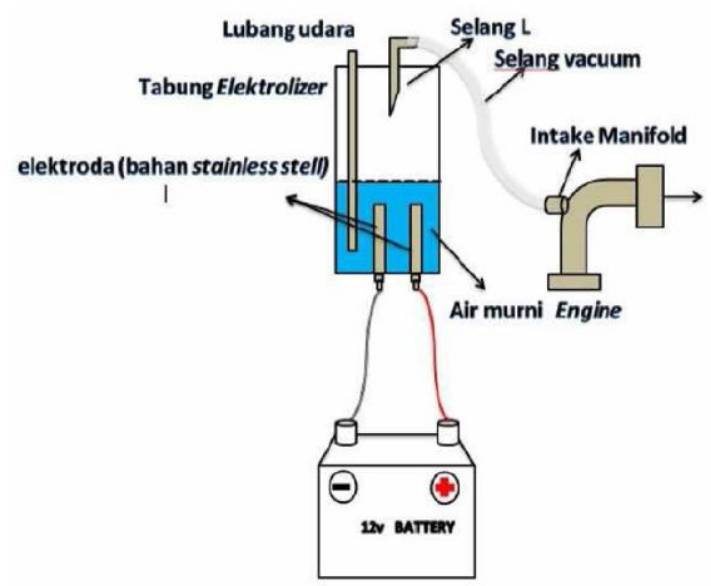

Gambar 8. Skema pemasangan alat elektrolizer

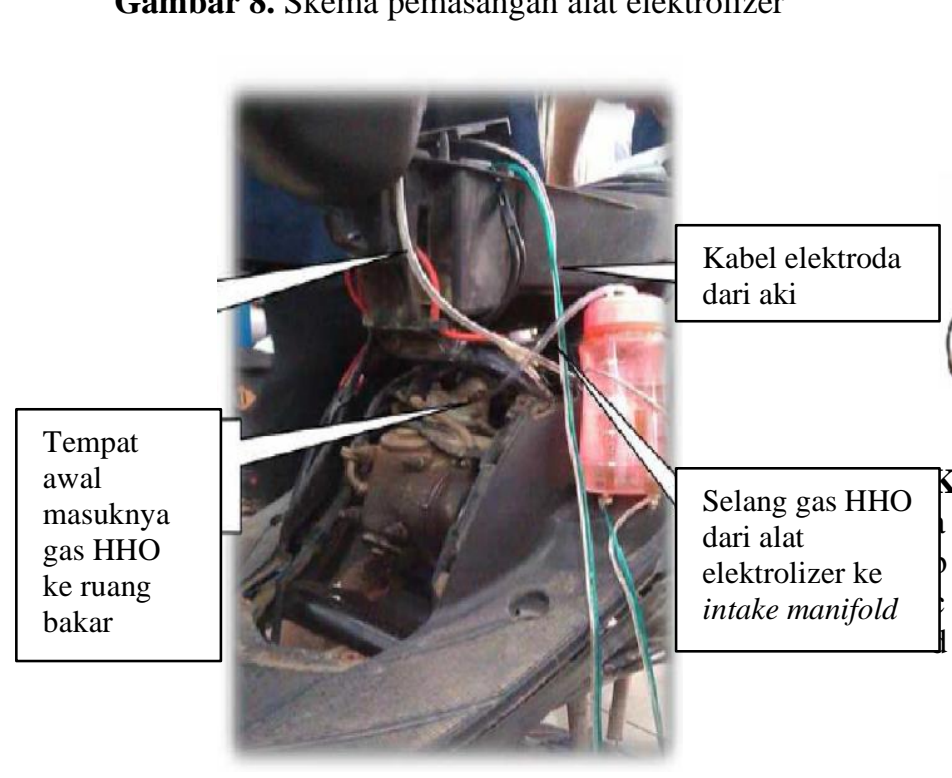

Gambar 9. Pemasangan dan pengujian alat elektrolizer

Hasil penelitiannya menunjukkan nilai presentase $\mathrm{NaHCO}_{3}$ yang menghasilkan efisiensi tertinggi terhadap penghematan bahan bakar adalah pada rentang 2,5-3\%. Data hasil penelitian dapat dilihat pada Gambar 10 dengan melihat waktu yang diperlukan untuk menghabiskan bensin sebanyak 150 $\mathrm{mL}$. Pada gambar tersebut menunjukkan penghematan bahan bakar yang didasari atas waktu dan \% larutan $\mathrm{NaHCO}_{3}$.

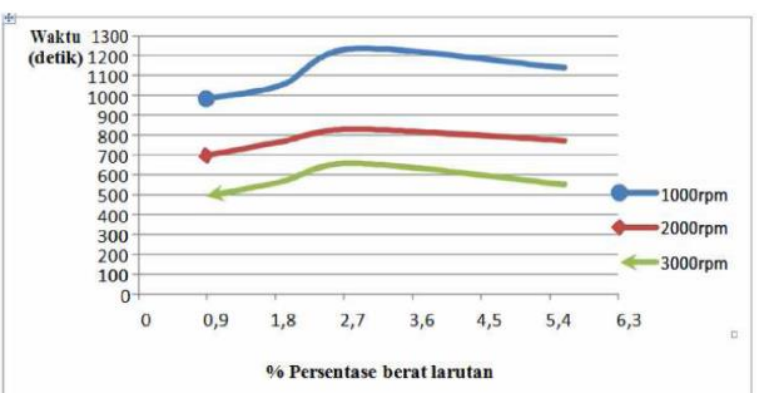

Gambar 10. Diagram penghematan bahan bakar berdasarkan waktu dan \% berat larutan
Selain itu, berdasarkan hasil penelitian Setiawan (2018) yang menyebutkan bahwa dengan ditambahkannya gas hidrogen hasil elektrolisis air terhadap kendaraan sepeda motor dengan variasi campuran air dengan $\mathrm{NaOH}$ memberi pengaruh terhadap emisi gas buang kendaraan. Penambahan gas hidrogen beserta campuran $\mathrm{NaOH}$ akan membuat bahan bakar premium semakin irit. Semakin tinggi campuran $\mathrm{NaOH}$ maka gas hidrogen yang dihasilkan semakin banyak dan emisi semakin berkurang. $\mathrm{NaOH}$ berperan sebagai katalis yang dapat mempercepat jalannya reaksi. Adapun skema proses elektrolisisnya dapat dilihat pada Gambar 11.

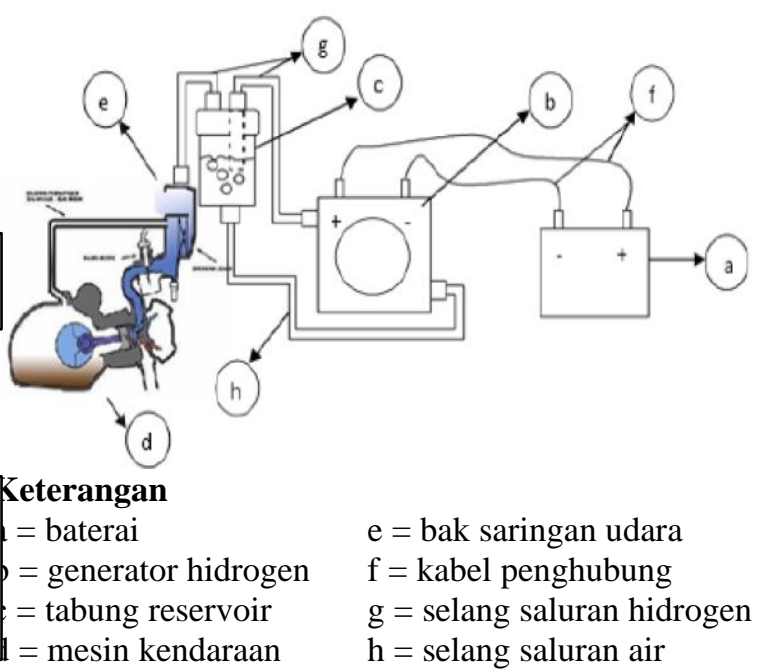

Gambar 11. Skema Proses Elektrolisis

Kendaraan yang banyak digunakan saat ini salah satunya adalah sepeda motor. Sering kita lihat di jalanan berbagai tipe sepeda motor dimulai dari yang terbaru hingga motor tua sekalipun masih sering kita jumpai. Sering kita rasakan knalpot yang lebih berbau dari motor-motor tua yang menandakan banyaknya pula polusi yang dikeluarkan dari motor tersebut. Kita sadari bahwa semakin lama usia suatu kendaraan maka kinerja mesinnya pun akan berkurang. Hal tersebut dapat diantisipasi sesuai dengan penelitian yang dilakukan oleh Cosina (2018).

Pada bahan bakar ditambahkan gas Hidrogen dengan tujuan meningkatkan kinerja mesin. Gas Hidrogen diperoleh dari reaksi elektrolisis yang diterapkan pada sebuah reaktor. Gas Hidrogen yang dihasilkan masuk melalui metode Inlet Manifold and Inlet Port Injection. Kinerja mesin motor meningkat atau tidak dengan melihat uji data performa dan unjuk kerja mesin.

Setelah ditambahkan gas Hidrogen pada bahan bakar, rata-rata torsi mesin mengalami peningkatan seperti yang dapat dilihat pada Tabel 1.

Tabel 1. Hasil Pengujian Torsi pada Berbagai Variasi Arus Reaktor Hidrogen 
Jurnal Pendidikan dan Aplikasi Industri (UNISTEK)

Vol. 8 No. 1 Februari 2021

p- ISSN : $0126-4036$

e- ISSN : $2716-0416$

\begin{tabular}{ccccc}
\hline \multirow{2}{*}{$\begin{array}{c}\text { Putaran } \\
\text { mesin } \\
(\mathrm{rpm})\end{array}$} & \begin{tabular}{c} 
Pertamax \\
\cline { 3 - 5 }
\end{tabular} & \multicolumn{3}{c}{ Rata-rata Torsi Mesin } \\
\cline { 3 - 5 } & $\mathbf{N})$ & $4 \mathrm{~A}$ & $5 \mathrm{~A}$ & $6 \mathrm{~A}$ \\
\hline 3000 & 8,893 & 8,986 & 9,23 & 9,375 \\
\hline 4500 & 7,77 & 7,963 & 8,163 & 8,25 \\
\hline 6000 & 8,216 & 8,533 & 8,74 & 8,816 \\
\hline 7500 & 7,043 & 7,406 & 7,653 & 7,795 \\
\hline
\end{tabular}

Torsi merupakan ukuran kemampuan mesin untuk melakukan kerja. Nilai torsi yang semakin besar menunjukkan pembakaran di dalam mesin lebih baik. Terlihat dari Gambar 12, dengan ditambahkannya gas Hidrogen membuat nilai torsi semakin meningkat. Hal tersebut berdampak sangat baik bagi kendaraan itu sendiri.

Gas Hidrogen dapat diperoleh pula dari proses elektrolisis plasma. Menurut penelitian yang dilakukan oleh Ariawan (2010), melaui proses elektrolisis plasma akan diperoleh produksi Hidrogen yang lebih banyak jiak dibandingkan dengan proses elektrolisis biasa. Sama halnya menurut Mizuno (2003) yang menyebutkan bahwa melaui elektrolisis plasma mampu meningkatkan pembentukan Hidrogen hingga delapan kali lipat dibadnidng dengan proses elektrolisis. Proses elektrolisis plasma dilakukan pada tegangan yang terbilang tinggi sehingga dihasilkan konduktivitas listrik yang tinggi pula yang membuat proses pemutusan ikatan pada air semakin meningkat.

\section{Kesimpulan}

Masalah pencemaran lingkungan yang diakibatkan oleh kendaraan merupakan permasalahan umum yang diketahui banyak orang. Salah satu solusinya adalah dengan beralih pada penggunaan bahan bakar nonfosil yaitu bahan bakar hidrogen yang tentunya ramah lingkungan. Selain tidak menghasilkan polusi, dengan penambahan hidrogen pada bahan bakar yang sudah ada pun dapat membuat irit bahan bakar tersebut dan meningkatkan unjuk kerja mesin bensin serta mengurangi emisi gas buang.

Hidrogen dapat diperoleh dari bahan yang berlimpah yaitu air dengan proses elektrolisis. Adapun cara lain untuk memperoleh gas hidrogen yaitu melalui teknik SMR, petroleum refining, dan coal gasification namum ketiganya masih tetap memerlukan gas alam sebagai bahan produksinya. Pembuatan gas hidrogen melalui proses elektrolisis sebetulnya sudah dilakukan di luar negeri sana maupun di Indonesia dari beberapa tahun lalu. Namun yang masih menjadi tantangan bagi kita semua adalah bagaimana caranya agar kita dapat beralih ke penggunaan bahan bakar hidrogen yang sudah dipastikan kelebihannya dibanding dengan bahan bakar yang sampai saat ini masih digunakan.

\section{Daftar Pustaka}

Ariawan, B. (2010). Sistem Produksi Hidrogen dengan Elektrolisis Plasma Nontermal dalam Media Larutan Gliserol - KOH. Skripsi. Universitas Indonesia.
Bhardwaj, S., Verma, A. S., \& Sharma, S. K. (2014). Effect Of Brown Gas On The Performance Of A Four Stroke Gasoline Engine. International Journal of Emerging Technology and Advanced Engineering. 4 (1), hlm. $300-308$

Carvaganza.com. (2018, 12 Maret). Honda Clarity Fuel Cell, The Silent Future. Diakses pada 24 November 2020, dari https://carvaganza.com/honda-clarity-fuel-cellthe-silent-future/

Cosina, F. A. (2018). Pengaruh Penggunaan Hidrogen Hasil Elektrolisis Terhadap Performa Mesin Pada Sepeda Motor. Sainteknol: Jurnal Sain dan Teknologi. 16 (2), hlm. $167-176$.

Gallardo, F. I., et al. (2020). A Techno-Economic Analysis Of Solar Hydrogen Production by Electrolysis In The North Of Chile And The Case Of Exportation From Atacama Desert To Japan. Elvesier: Science Direct, hlm. 1-20.

Greenstone, M. \& Fan, Q. C. (2019). Kualitas Udara Indonesia yang Memburuk dan Dampaknya terhadap Harapan Hidup. Air Quality Life Index.

Mamilla, V. R., et al. (2018). Production of Brown's Gas using Hydroxy Generator. International Journal of Engineering \& Technology. 7 (4.5), hlm. $428-457$.

Marlina, E., Wahyudi, S., \& Yuliati, S. (2013). Produksi Brown's Gas Hasil Elektrolisis $\mathrm{H}_{2} \mathrm{O}$ Dengan Katalis $\mathrm{NaHCO}_{3}$. Jurnal Rekayasa Mesin. 4(1), hlm.53 - 58.

McMurry, J. \& Fay, R.C. (2003). Chemistry Fourth Edition. New Jersey: Prentice Hall.

Mizuno, T., Akimoto, T. \& Ohmori, T. (2003). Confirmation of Anomalous Hydrogen Generation by Plasma Electrolysisi. In 4th Meeting of Japan CF Research Society. Iwate, Japan : Iwate University.

Mursid, S.P. \& Hamzah, Z. (2013). Pengendalian Gas Brown Pada Elektroliser Untuk Meningkatkan Unjuk Kerja Motor Bakar. Jumal Teknik Energi.3 (2), hlm. $250-259$.

Setiawan, Y. \& Salam, F. (2018). Gas Hidrogen Pada Proses Elektrolisis Terhadap Emisi dan Konsumsi Bahan Bakar. Flywheel: Jurnal Teknik Mesin Untirta. 4 (1), hlm. 10 - 13.

Sunarya, Y. (2007). Kimia Umum. Bandung : Alkemi Grafisindo Press.

Suprianto, T. \& Widiawan, N. M. (2016). Pengaruh Larutan Natrium Bikarbonat pada Alat Elektroliser terhadap Penghematan Bahan Bakar. Dalam Prosiding SNRT (Seminar Nasional Riset Terapan). Banjarmasin, Indonesia: Politeknik Negeri Banjarmasin.

Syukri. (1999). Kimia Dasar I. Bandung : Penerbit ITB

Whitten, K.W., Davis, R.E., Peck, M.L., \& Stanley, G.G. (2014). Chemistry $10^{\text {th }}$ Edition. USA: Brooks/Cole Cengage Learning. 
Jurnal Pendidikan dan Aplikasi Industri (UNISTEK)

Vol. 8 No. 1 Februari 2021

p- ISSN : 0126 - 4036

e- ISSN : $2716-0416$ 